Document downloaded from:

http://hdl.handle.net/10251/155004

This paper must be cited as:

Sutrisna, M.; Pellicer, E.; Torres-Machí, C.; Picornell, M. (2018). Exploring earned value management in the Spanish construction industry as a pathway to competitive advantage. International Journal of Construction Management. 20(1):1-12.

https://doi.org/10.1080/15623599.2018.1459155

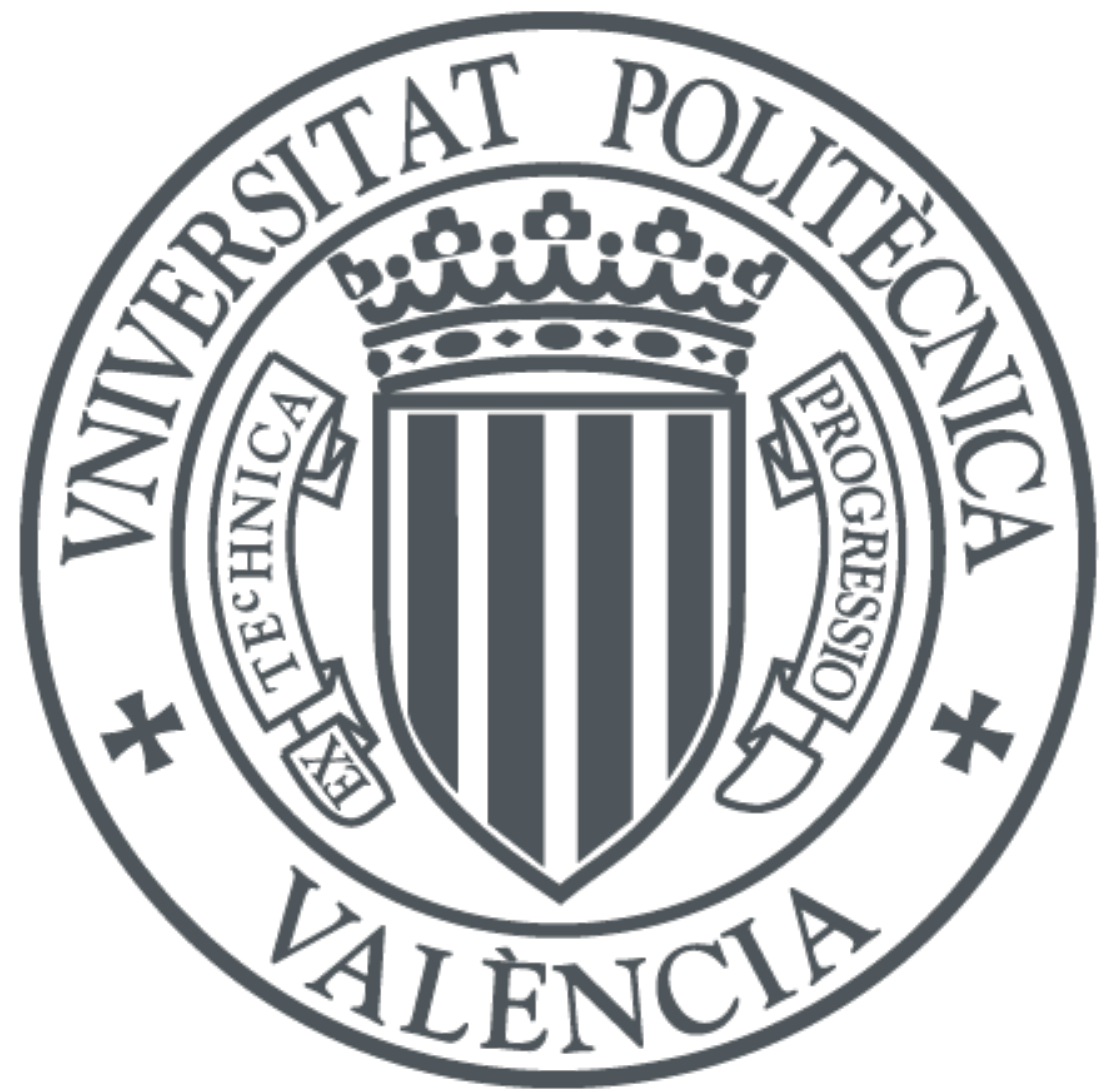

The final publication is available at

https://doi.org/10.1080/15623599.2018.1459155

Copyright Taylor \& Francis

Additional Information 


\title{
EXPLORING EARNED VALUE MANAGEMENT IN THE SPANISH CONSTRUCTION INDUSTRY AS A PATHWAY TO COMPETITIVE ADVANTAGE
}

\section{Monty Sutrisna}

Associate Professor \& Head of Department, Construction Management Department, Curtin University, Kent St., Bentley WA 6102, Australia, phone \#61.8.9266.3872, email monty.sutrisna@curtin.edu.au.

\section{Eugenio Pellicer}

Corresponding Author: Associate Professor, School of Civil Engineering, Universitat Politécnica de València, Camino de Vera s/n, 46022 Valencia, Spain, phone \#34.963.879.563, fax \#34.963.877.569, email pellicer@upv.es.

\section{Cristina Torres-Machí}

Assistant Professor, School of Civil Engineering, Universitat Politécnica de València, Camino de Vera s/n, 46022 Valencia, Spain, phone \#34.963.879.563, email critorma@upv.es.

\section{Miguel Picornell}

Program Manager, Nommon Solutions and Technologies S.L., C/ Cañas 8, 28043 Madrid, Spain, phone \#34.606.708.783, email miguel.picornell@nommon.es.

\begin{abstract}
As a well established discipline and profession, project management has its distinctive tools and techniques. One of them that has been considered the embodiment of the core principles of project management is the Earned Value Management (EVM). In managing construction projects, the EVM has been considered as a suitable tool and hence, has been implemented in
\end{abstract}


various construction industry but absent in some others. Taking into account the dynamic environment where construction companies have to operate, particularly in turbulence environments as the direct result of recent global economic downturn, this paper explores the potential implementation of EVM in one of the construction industry, the Spanish construction industry. The outcomes confirm the needs for and feasibility of implementing EVM as a structured approach in the industry to reposition the Spanish construction industry with the long term view to increase its project management maturity level as a pathway to gaining competitive advantage.

KEYWORDS: Construction Industry, Economic Crisis, EVM, Project Management, Spain

\section{INTRODUCTION}

Project management has established itself as a mature multi-discipline profession that continuously grows with its distinctive tools and techniques in managing projects (Winch 2002; Suk et al. 2016). These well-established tools and techniques have been specifically designed to support project managers in monitoring and controlling activities at any point in time during the course of the project (PMI 2013). However, in dealing with construction projects, many variables contribute to the already complex operation to deliver these projects. There are typically continuous demands for different and sometimes contesting requirements including speed, cost and quality control, health and safety, sustainability, and so on (Gidado 1996; Sertyesilisik 2016).

There is a large volume of published studies describing the benefits created by project management. A survey undertaken by Bryde (2003) found that, where project management 
was developed in a formal fashion, there was a perception that the results were successful. An in-depth analysis of the benefits derived from project management was conducted by the Project Management Institute (Thomas and Mullaly 2008). This study, involving 65 organisations from 14 countries, concluded that project management creates tangible and intangible benefits. Among tangible benefits of project management, concepts such as cost savings and customer retention are included; whereas improvements in decision-making and enhanced communications and collaboration, among others, are considered as intangible benefits. Similarly, studies undertaken in Malaysia (Din et al. 2011) and in the United Arab Emirates (Mir and Pinnington 2014), found a statistically positive relationship between project management and project success. Together, these studies indicate that the implementation of project management practices may improve the practices of construction companies. This improvement is especially important for the survival and competitiveness of construction companies operating in turbulent environments. Such turbulence in the environment can be influenced by many factors, but taking into account the recent global economic downturn in 2007, one of the most severely affected is the Spanish construction industry.

Prior to the global financial crisis, the Spanish construction industry has been considered one of the most dynamic sectors in the Spanish economy in terms of both job creation and production: from 2.7 million employees and a revenue of 371.0 billion Euros in 2007 to 0.97 and 101.3 respectively in 2015; this means a decrease of $64 \%$ in employment and $73 \%$ in production (SEOPAN 2016). Furthermore, public procurement dropped 79\%, from 46.7 billion Euros in 2006 to 9.9 billion Euros in 2015 (SEOPAN 2016). The 2007 crisis saw the end of the long phase of expansion enjoyed by the Spanish economy in the previous decade and the beginning of an inevitable adjustment in the real estate and, consequently, in the construction sector (Oviedo-Haito et al. 2014). 
In dealing with turbulent, complex, uncertain and dynamic situations, the Earned Value Management (EVM henceforth) has emerged as a robust tool in supporting project managers and has been regarded as one of the major project management tool that embodies the most fundamental principles of project management in practice (Sutrisna et al. 2013, 2012; Marzouk and Hisham 2014; Picornell et al. 2016). Previous research has demonstrated a relatively strong relationship between EVM and procect success as well as the important contribution of EVM's WBS and S-Curve to the formation and administration of project contracts (Marshall et al. 2008; Chen et al. 2016; Kim et al. 2016). The Project Management Institute (PMI 2013) defines Earned Value Management as a methodology that combines scope, schedule, and resources measurements to assess project performance and progress. Performance is measured by determining the budgeted cost of the work performed (i.e. earned value) and comparing it to the actual cost of the work performed (i.e. actual cost). Progress is measured by comparing the earned value to the planned value. By a constant comparison of these variables, cost and schedule variances can be monitored as well as the schedule performance index and cost performance index. Subsequently, the estimation completion date, estimation completion cost and cost to complete can be calculated. Further details on the mechanics of EVM, its calculation and further development can be found in various relevant textbooks and papers (e.g. Brandon 1998 Anbari 2003; Vanhoucke 2012; Marzouk and Hisham 2014; Kim et al. 2016).

As early as 1990s, EVM has been widely adopted in the United States, particularly in the defence and aerospace industries. The Department of Defence in the United States for instance, has been active in both promoting and requiring the use of EVM in its projects (Fleming and Koppelman 2005). However, it became evident that the capabilities of EVM in managing and controlling projects has also been realised in other sectors including in construction and also 
beyond the United States. A global survey involving Project Management Institute (PMI) members (Liberatore et al. 2001) reported the extensive use of EVM, particularly as a project control mechanism in construction projects. Another survey (NAO 2005) also reported that EVM is mandatory for large projects not only in the USA, but also in Australia and Europe (particularly in Sweden and the UK). However, the use of EVM in other construction industry such as in Spain has not yet been reported.

From the changing landscape discussed above, there appears to be a real need for the Spanish construction industry to change the way of working and re-position itself in the competitive construction market. The construction sector is, indeed, a key element on the Spanish economy, being a booster to economic growth before the economic crisis (with a contribution of $21 \%$ of GDP in 2007) but also a critical sector in job losses accounting for more than $50 \%$ of job losses between 2007 and 2014, which dropped the contribution of GDP to 9\% in 2014 (SEOPAN 2016). The significance of the construction industry in the Spanish economy (44,000 housing units were finished in 2014, according to SEOPAN 2016) means that improvements in its construction industry practices will benefit the economy on a large scale. The concept of project management, in general, as well as the EVM in particular, has been reported receiving recognition to 'better' manage and deliver construction projects, although implementation has been gradual and slow (Pellicer and Victory 2006; Pellicer et al. 2016). However, the Spanish construction industry has been characterised by the management style of managers that relies heavily on ad-hoc approaches in managing their projects and generally underplays the importance of planning (Aram and Walochik 1997; Oviedo-Haito et al. 2014). Particularly, in the public sector, the shortcomings have been identified as inadequate prequalification system of contractors and designers, insufficient training of public servants, political considerations 
prevailing over real needs and, mainly, the low project management maturity (de la Cruz et al. 2006).

The project management maturity itself has been considered a widely accepted concept in the project management discipline and can be used as a useful road map to develop and implement strategy for improvement (Kerzner 2005; Yazici 2009). The relatively slow implementation of project management concepts, techniques and tools with all the identified problems above can be attributed to the lower level of project management maturity in the Spanish construction industry, mainly in its public sector but also symptomatic in its prívate sector (Sutrisna et al. 2013; Pellicer et al. 2016). In combination with other factors such as organizational culture, the project management maturity concept can be utilised to improve efficiency and effectiveness of the projects undertaken by an organisation as well as improving internal (such as savings, sales growth, and overall business performance) and external (includes market share and competitive position) performances of the organisation (Yazici 2009). Even though not considered as the 'silver bullet' that can provide competitive advantage, the project management maturity concept can be used as a pathway in achieving competitive advantage (Jugdev and Thomas 2002).

In light of the ongoing discussion, a research project has been set attempting to explore the potential of adapting EVM in the Spanish construction industry as an important milestone towards repositioning the industry, particularly within the context of project management to increase its competitiveness. The findings from a questionnaire survey in this research are presented here indicating the real potential for implementing EVM. The state of art of project management practices in the Spanish construction industry and current practices that will support components of EVM are revealed and discussed, followed by recommendation for the 
way forward. In concluding the paper, a wider implication of the findings was also discussed, drawing lessons learned from this exploration that may help supporting subsequent attempts to study the potential of implementing EVM in other construction industries.

\section{RESEARCH METHODOLOGY}

Research methodology refers to the principles and procedures of logical thought processes which are applied to a scientific investigation (Fellows and Liu 1997; Holt and Goulding 2014). Thus research methodology encapsulates the overall strategy implemented in achieving the aim and objectives of the research. This research has been designed following the principles of mixed methods approach. There is a strong suggestion within the research community that both quantitative and qualitative in most cases should be complementary and therefore can be implemented together in conducting research commonly known as mixed research method (Onwuegbuzie and Leech 2005; Sutrisna 2009). Thus quantitative and qualitative research methods and techniques can be utilised to form a more holistic understanding in explaining the phenomenon being researched. When implementing a mixed research methods, in some cases, it has been recognised the difficulty to avoid domination of one method that may downplay the others into supportive methods (Creswell 1994; Robson 2011). The capability of this approach to bring a more realistic and holistic understanding to the fore has made mixed methods approach suitable in conducting research involving highly complex phenomenon (Robson 2011).

The selection of the appropriate research strategy will mainly be influenced by the nature and the objective of the research. Yin (2013) advocated three conditions to be considered in choosing research strategy: (1) the type of research question posed; (2) the extent of control a 
researcher has over actual behavioural events; and (3) the degree of focus on contemporary events. Following an in-depth literature review, it became apparent that the custodians of the information and knowledge to be sought in this research are the construction project management practitioners in the construction industry. Therefore, questionnaire survey and follow up interviews involving construction project management practitioners in the Spanish construction industry have been selected in this research in order to satisfy the aim and objectives of this research. This paper reports the findings from the questionnaire data collection and analysis.

The questionnaire technique generally includes all techniques of data collection in which respondents would be asked to respond to a set of questions in a certain order (de Vaus 1996; Robson, 2011). A self-administered postal questionnaire with space for feedback at the end has been designed for this research. The questions in the questionnaire were developed to explore the state of art of the implementation of project management techniques in the Spanish construction industry as well as to investigate the readiness of the Spanish construction companies to implement EVM in their practices by identifying enablers in the current practice. In conducting questionnaire surveys, the major considerations are typically the sample size, data collection procedures, analysis and measurement. The credibility of the respondents is also considered an important factor in this research. When the goal of the research is not to statistically generalise but to obtain insights into a phenomenon, individuals, or events, (i.e. analytical generalisation as per Miles et al. 2013) then it can be considered appropriate to purposefully selects individuals, groups, and settings that maximise understanding of the underlying phenomenon (Onwuegbuzie and Collins 2007). Due to the exploratory nature of the research without an intention to statistically generalise at this stage, it was considered appropriate to conduct purposive sampling in this research. 
A semi structured questionnaire containing combinations of Likert scale and ranking order with additional feedback spaces was specifically designed for this research. Due to the exploratory nature of the investigation, i.e. not yet to generalise, the respondents were targeted with purposive sampling method implementing snowballing technique as described in Robson (2011). The targeted respondents were practitioners involved with managing construction projects in Spain for at least 5 years from the university's database. These targeted practitioners have been involved with various construction projects including buildings and infrastructure projects in different regions of Spain with the majority of them working for national and multinational construction companies in Spain. In the questionnaire, practitioners were asked about their experience in project management during their professional career and not on a specific project. The number of the targeted respondents was 60 project managers from different levels. The questionnaire were originally designed in English but then translated into Spanish language for clarity and practical reasons. Fifty six completed questionnaires were received. The characteristics of the respondents are provided in Table 1.

\section{$<$ TABLE 1 HERE $>$}

Results from the survey include the respondents' perception on the state of the art of project management and its implementation in Spanish construction industry and current practices in the industry relevant to EVM components. Descriptive statistics and non-parametric Friedman ranking test were conducted to analyse the data. The questionnaire survey consist of measurement of respondents degree of agreement using 5 point Likert scale as well as their perceived importance of various relevant factors identified from the literature in the format of ranking. The analysis of the questions involving 5 point Likert scale (ranging from Strongly 
Disagree to Strongly Agree) was conducted by representing the points in weighting (w) with values of $-2,-1,0,1$, and 2 respectively. The mean $(\bar{x})$ of the number of samples $(n)$ is then calculated as in Equation 1.

$$
\bar{x}=\frac{\sum_{i=1}^{n} w_{i}}{n}
$$

The respondents were considered accepting the statement where the mean $(\bar{x})$ of response is $\geq$ 0 (i.e. the consensus of different level of agreement was aggregated into a single output). This was then included in the discussions of the findings. In order to better illustrate the trend in responses, the median value of the questions involving the Likert scale is also included in the discussion.

The analysis of the ranking data involves the non-parametric Friedman test in evaluating differences in location for the $\mathrm{k}$ factor-level populations. When defining $\mathrm{T}_{i}=$ total of the ranks for the ith population, the Friedman test is defined as in Equation 2.

$$
F R=\frac{12}{b k(k+1)} \sum_{i=1}^{k} T_{i}^{2}-3 b(k+1) \quad \text { (Equation 2) }
$$

where $b=$ number of blocks and $k=$ number of factor levels (populations). When asked to rank items in the questionnaire, some respondents only ranked 1,2 or 3 and have left the other items without ranks. This can be considered Missing Not At Random (MNAR) situation and therefore, it was considered necessary to apply single imputation technique using the worsecase scenario as described in Fitzmaurice et al. (2004). In this particular case, the worse-case scenario is defined as $\left(n_{i}+1\right)$ where $n_{i}$ is the last rank (i.e. the largest rank) answered by a respondent in that particular question. Whilst there are ongoing debates regarding the use of 
single imputation (please refer to Howard 2012), it is considered appropriate in this particular case as the aim is limited to the determination of position of the items in the ranking order whilst at the same time taking all responses into consideration.

\section{RESULTS AND DISCUSSION}

The results of the survey and relevant discussion of the findings can be mainly grouped into three major themes, namely 'the state of art project management in Spain' as well as components of EVM already exists in Spanish construction industry practices that includes 'construction project planning' as well as 'construction progress and actual cost monitoring'. These findings and discussions are presented below leading to the potential of implementation and the way forward.

\subsection{THE STATE-OF-ART OF PROJECT MANAGEMENT}

Respondents were provided with a series of statements relevant to the implementation of project management techniques and tools in the Spanish construction industry and the results of this section are presented in Table 2. There was a consensus in recognising a need for further use and application of project management tools and techniques in managing construction projects in Spain $(\bar{x}=0.62$; median $=1)$. This was found consistent with the agreement among the respondents that project management concepts are not perceived as novelties and these concepts are widely accepted in the Spanish construction industry $(\bar{x}=0.51$; median $=1)$. Thus, the practitioners confirmed that the project management concepts have been around and recognised as important for relatively a long time and yet there is still a need to fully embrace

and, more importantly, further implement project management in the construction industry 
practices. This corroborates the conclusion reported by Pellicer and Victory (2006) regarding the slow implementation of project management in Spanish construction industry.

\section{<TABLE 2 HERE $>$}

A research in the UK construction industry linked the continuous failure of construction projects in achieving project objectives to the failure of 'properly' implementing project management in these construction projects (Brown and Adams 2000). In relation to this, the subsequent questions in this section of the questionnaire related to the recognition, acceptance and the implementation of project management tools/techniques have received mixed results that brought the mean score close to neutral $(\bar{x}=-0.07, \bar{x}=-0.16$, and $\bar{x}=0.16$ respectively; median in the three questions was 0) indicating disagreement among the respondents. A field for respondents to write down their feedback in every section of the questionnaire was provided and in this case has shed a light on this disagreement. Five respondents indicated a disparity in project management practice between large construction companies and small construction companies. Whilst project management principles have been embedded within large companies' procedures, it is rarely the case with smaller construction companies. The large construction companies have been implementing project management techniques and principles in their practices, procedures and training. This includes formal planning in advance, project monitoring and control to allow proactive decision making and profits optimisation.

Furthermore, project managers of relatively larger projects have been reported to put more focus on enhancing communications among project stakeholders and among different parts of the organisation than compared to the ones of smaller projects (Kim et al 2003). On the other hand, smaller construction companies are typified by their ability to adapt quickly in their 
operation depending on the project needs in an informal manner. The over reliance towards the informal and ad-hoc approaches, and in many cases subjective decision-making by very few key people, have prevented these smaller companies (typically dealing with smaller and simple projects or parts of a project) from extending their knowledge base and taking advantage from contemporary techniques and tools that can be used to optimise their profits (Kim 2014). Koskella and Howell (2002) argued that in relatively smaller and simple projects, problems could be solved informally and without wider consequences whilst it may not be the case with the larger and complex projects. When discussing about EVM implementation, Kim et al. (2003) reported that EVM implementation in smaller projects were much simpler and at less detailed levels compared to the ones in larger projects. Thus despite the size of the construction organisations and projects, it was found feasible for EVM to be implemented in the Spanish construction industry.

Despite the size of the company, the respondents confirmed that the main focus of construction project management in Spain is the cost. Table 3 presents the results of the Friedman ranking analysis. Cost was ranked $1^{\text {st }}$ by respondents and far outranked other areas including time, quality, health and safety, sustainability, client satisfaction and personal/public relations. Thus, most efforts in managing construction projects in Spain appeared to be dominated by the intention to deal with and control cost. Potential disadvantages of this approach may involve inefficiency, false economy and loss of opportunity to take meaningful actions in earlier stages of construction projects. The more contemporary views on project management have encouraged various efforts in overcoming the perceived inadequacies of classical dimensions of cost, time and quality (Yu et al. 2005). As an example, long term reputation of the contracting firm and their chance for repeat businesses are now regarded as a strategic objective. Moving away from perceiving projects as one-off ventures, they are now also 
perceived as one of the building blocks in the formulation and execution of corporate strategy which contribute to organisational goals and success, mainly in terms of competitive positioning in the global marketplace (Dinsmore 1998). Thus there is a need to shift the current project management focus in the Spanish construction industry from cost to also include other dimensions. This opens up the opportunity to implement EVM in this sector to drive the shift to increase the project management maturity as a pathway in achieving competitive advantage. This potential of implementing EVM is mainly characterised by the technique in EVM that uses financial values to also represent other components such as time and variances which can be expected to make acceptance of EVM easier in the Spanish construction industry.

$<$ TABLE 3 HERE $>$

\subsection{CONSTRUCTION PROJECT PLANNING}

The findings of the research have so far confirmed the need to improve practice and the potential to implement EVM in the Spanish construction industry to achieve that. Prior to implementation of any new system, there is a need to better understand the landscape and the existing practice. The other part of the questionnaire was also designed to capture the existing practices in the Spanish construction industry relevant to the three main components of EVM, namely plan (budget and programme), earned (progress tracking), and actual cost. Respondents were provided with a series of statements relevant to the practices of planning for construction projects including budgeting and programming/scheduling and the results are presented in table 4.

$<$ TABLE 4 HERE $>$ 
Whilst the original cost estimation at the pre-tender stage usually corresponds to the Work Breakdown Structure (WBS) in the programme $(\bar{x}=0.80$; median $=1)$, the main basis of estimation was also found to be the quantity of work to be delivered $(\bar{x}=0.58$; median $=1)$. There was a relatively strong consensus $(\bar{x}=1.15$; median $=1$ ) in admitting the common practice of limiting the use of tender stage programme/schedule (original budget and programme/schedule) into the pre-construction stage only and then develop a completely new programme/schedule exclusively for construction stage. This was found important as the newly prepared programme will in most cases becomes the basis for the project execution to the level of activities in its WBS $(\bar{x}=0.73$; median $=1)$.

Whist the quantity of work and productivity of resource are typically used as the determining factors in programming/scheduling and cost estimating (Cioffi 2004), it has also been recommended to transform a WBS from schedule-orientation (or resource oriented) into deliverable-orientation as the project progresses into delivery phase (Rad 1999). Thus, the pretender programme/schedule will not typically be as detailed as the one produced for execution (Nima et al. 2001). However, there is a potential danger to fall into the trap of 'a case of tail wagging the dog' (Laufer and Tucker 1987, 263), where the execution plan deviated so much from the formal plan instead of the advanced formal planning guiding the execution plan. The typical reasons for this to happen in a construction project were the short term nature and 'real time' need of construction site activities. This reduced role of the formal pre-tender programme/schedule can somehow undermined the original intention to develop the programme/schedule in the first place if the deliverable-orientation programme/schedule was developed from scratch and very different from the formal pre-tender one. This was further confirmed by the answer of the respondents to the subsequent question that ranked the 'type of activities’ as a relatively less important factor to be considered when preparing the construction 
budget and programme in Spain. Thus the main focus was on the quantity of work to be delivered and how long the resources can deliver and complete the job. Table 5 presents the results of the Friedman ranking analysis.

$<$ TABLE 5 HERE $>$

This situation again opens up the door for implementing EVM in Spain. Despite the procurement route selected for a particular construction project, the first component of EVM, namely the Planned Value (PV) will be determined prior to the execution, consistently used as a baseline and will typically be updated based on the agreed values (Bower 2007). Thus the use of EVM will impose a robust planning, estimating and budgeting to be conducted in the earlier stage of a construction project in Spain.

\subsection{CONSTRUCTION PROGRESS AND ACTUAL COST MONITORING}

Respondents were also provided with a series of statements relevant to the practices of monitoring the progress and the actual cost in construction projects in Spain. In the EVM terminology, these are the Earned Value (EV) and the Actual Cost (AC) components. The results are presented in table 6.

$<$ TABLE 6 HERE $>$

The respondents revealed that the tracking of the construction progress are not done merely to comply with contractual requirements and for progress payment purposes only $(\bar{x}=-1.09$; median $=-1$ ). The main basis used to track the construction project progress in Spain was found 
to be the record of actual project expenditure up to a certain point in time $(\bar{x}=0.49$; median $=$ 1) which is the Actual Cost (AC) component in the EVM. The actual costs are recorded based on cost centres and, even though do not necessarily correspond directly to the WBS, they can still be traced back to the relevant WBS $(\bar{x}=0.73$; median $=1)$. However, the frequency of recording the actual cost was not found to be on a daily basis $(\bar{x}=-0.64$; median $=-1)$ whilst the evaluation of the actual cost against the original budget can occur at different point in time, i.e. not really constrained by a certain frequency as there was not a consensus on a certain agreed/planned frequency $(\bar{x}=0.05$; median $=0)$. When asked about the main technique used for tracking the progress in construction projects in Spain, the results were inconclusive between percent completion of activities based on WBS and actual measurement of physical progress mainly for payment purposes $(\bar{x}=0.09$; median $=0.5$, and $\bar{x}=0.09$; median $=0$, respectively) indicating variances in practice.

Whilst there appears to be a wide recognition of progress tracking as a necessary project control mechanism, the practice of using the actual cost or project expenditure to represent progress can be considered a more 'traditional' project management practice (Suk et al., 2016) that embodies what exactly EVM is moving away from. The distinction of the earned value (progress to be achieved relative to the budget) from the actual cost (the actual project expenditure to date) in EVM offers a more accurate representation of the progress achieved so far whilst the use of project expenditure or actual cost alone can be misleading in many cases (Sutrisna et al. 2012). Thus, the separation can be considered one of the most fundamental enhancements in managing projects offered by the EVM. The survey also revealed the current focus or emphasis on the cost and quantity in monitoring construction progress. Whilst little has been achieved in tackling the problems associated with project progress monitoring and control in the construction industry, research efforts in the field of project control still focus on 
the development of cost control models (Hastak et al. 1996; Suk et al. 2016). In ensuring ontime completion of a construction progress, cost and quantity monitoring have not been regarded as suitable parameters to be monitored as this represents a weaker link between progress monitoring and project control (Eldin 1989; Navon and Haskaya 2006). In planning and controlling projects, the lack of integration, inconsistencies and/or disparity between the schedule related Work Breakdown Structure (WBS) and the cost related Cost Breakdown Structure (CBS) have been one of the main discussions since the 1980s and 1990s (e.g. Ibbs et al. 1987; Hendrickson and Au 1989; Rasdorf and Abudayyeh 1991), which appear to be happening here as indicated by the respondents. Accordingly, EVM has been defined as a fully integrated project 'cost-and-schedule' control system (Potts 2008). Thus the use of EVM will necessitate and nurture an integrated schedule-and-cost breakdown structure to be developed in the earlier stage of construction projects in Spain and to be consistently used during construction phase. 


\section{POTENTIAL FOR IMPLEMENTATION AND THE WAY FORWARD}

Practices that can be associated with higher level of project management maturity level were identified albeit limited to large construction companies and practitioners appear to recognize the need for further use and application of project management tools and techniques in managing construction projects in Spain. From the on-going discussion so far with the view that EVM can be utilised to enhance project management maturity in construction firms in Spain as a pathway to achieving competitiveness, the importance as well as potential of implementing EVM in the Spanish construction industry become apparent. Various EVM components and precursor of EVM components already exist whilst the sector is suffering from inefficiency and counter-productivity. Therefore, EVM can be recommended as a new platform that can bring together existing practices aiming to improve practices and continuously increase the level of project management maturity. However, implementing EVM in such an environment requires genuine shift of the practitioners' mindset to fully value the benefits and not perceiving EVM simply as an additional burden to them nor an increased monitoring from top management of their individual performances. This so called 'internal resistance' has been well documented and reported in literature as one of the main challenges in implementing EVM in organisations (e.g. Antvik 1998; Thamhain 1998; Bower 2007).

From the data analysis, it became evident that there is a scope to implement EVM in the Spanish construction industry whilst project management maturity level of many construction companies in Spain can be considered rather low. The project management maturity model portrays a firm's positioning ranging from lower maturity of project management practices to solid practices and the related infrastructure that may be necessary to support their projects from an organisational point of view. Yazici (2009) demonstrated how organisations with 
higher project maturity are enabled to achieve substantial savings, increase sales growth, show better competitiveness compared to their competitors, and even establish best practices in their industry or service sector. Thus by increasing the project maturity of its construction projects and firms, the EVM can help to reposition the Spanish construction industry and in the longer term, sustain its competitiveness in the global market place. Whilst the project management maturity has been extensively covered elsewhere (e.g. Ibbs and Kwak 2000; Crawford 2002; Grant and Pennypacker 2006), implementing EVM can be generally seen as mainly improving the project planning and procedures, project data collection for further decision making and improvement, as well as project control aspects of managing projects. EVM provides a structured mechanism to formalise the project planning and procedures aiming for continuous improvement at level 5 (the highest level in project management maturity). EVM requires continuous project data capture to provide up-to-date project status. This in turn, enables well informed decision making to better control the project in a more formal, effective and meaningful manner. In a more indirect manner, EVM facilitates further integration between various parts of the organisation and as the result, promotes integration between these different organisational functions. If performed correctly, these improvements should lead to more cohesive teamworks and development of project driven environment which typifies organisations at level 5 in project management maturity. Figure 1 captures and summarises the transition from current practice towards EVM implementation.

Within the existing practice, there is a disconnect between the pre-construction and construction schedule, loose relationship between the cost estimate (budget) and schedule during the pre-construction phases which is likely continued into construction phase showing further disconnect between the schedule and expenditure. Implementing EVM can be perceived as a positive move towards reconnecting and synchronising pre-construction and construction 
schedule as well as between budget and schedule and between expenditures and schedule in both pre-construction and construction phases. Thus in the existing practice, the actual project management process focuses on the construction phases with a strong focus on cost tracking, quantity of the works and allocation/use of resources. In the implementing EVM phase, the project management involves components from pre-construction (planning) as well as construction (delivery and control), integrated within a holistic system. The project management focus is now on the integration and synchronisation of cost, expenditures, preconstruction schedule and construction schedule structured within the Planned Value (PV), Earned Value (EV) and Actual Cost (AC). The project planning and procedures are moving from unpredictable/ad-hoc towards formal, the project data collections are moving from none towards automatic collection with rigorous analysis, and project control is moving from poor to fully informed.

Further step-by-step progression from project management maturity model level 1 to level 5 can be found in many other literature on the subject. This transition is aimed at improving the project management maturity of the construction companies and construction industry in Spain that in the long term can pave up the ways to increase competitiveness. Therefore, based on the findings of this exploratory study, EVM can be strongly recommended to be implemented in the Spanish construction industry as a pathway to achieving competitiveness

\section{CONCLUSIONS}

EVM has been regarded one of the project management tools that embodies the most fundamental project management principles. EVM has also been considered supporting the achievement of higher project management maturity of construction organizations. The higher 
project management maturity has also been linked to pave the way for competitive advantage. In turbulent environments, competitive advantage has been seen as an essential way to survive. In the case of Spanish construction industry presented in this paper, the turbulence in the environment has created a unique set of challenges for their construction companies. Whilst most of these companies were able to 'afford' implementing the lower level of project management maturity in the 'good times', the market condition post financial downturn in 2007 has necessitated these companies to be more competitive. On the other hand, this inevitable necessity to be more competitive can also be seen as an opportunity and can be used to change the way of working towards creating further competitive advantage to the Spanish construction industry as a whole. From the findings of this exploratory study, it can be strongly recommended for the Spanish construction industry to implement EVM with the long term view to reposition by achieving and sustaining competitive advantage in the global market.

In this research, the figure 1 presented in the previous section was specifically developed based on data collected from the Spanish construction industry. However, a similar principal and methodology of assessing the connectivity and relationship between various key components in managing construction project can be applied in evaluating other construction industries with the view to indicate how EVM as a project management tool can support further improvement. It is important to note that this paper is not advocating EVM as a panacea or a 'silver bullet' [the terminology used by Jugdev and Thomas (2002) in illustrating a similar view] that can solve all problems in managing construction projects and immediately achieving organisational competitive advantage. Due to unique characteristics of each construction industry, further research (which fall beyond the scope of this paper) should identify components of EVM already exist (such as identified in this research for the Spanish construction industry for instance) followed by evaluating the need to improve the project planning and procedures, 
project data collection for further decision making and improvement, as well as project control aspects in managing projects, i.e. core components of project maturity model that EVM may contribute to in further designing the pathway towards achieving competitive advantage for that particular construction industry. The pathway should prescribe very clearly the changes and adjustment needed to implement EVM and address the components of project management maturity specific to that particular construction industry.

\section{ACKNOWLEDGEMENTS}

This research was partially supported by the Universitat Politècnica de València that funded a visitorship for the first author (action 19701344). The authors are also indebted to all the participants in this research, especially to Dr. Jaime Jiménez, as well as to the reviewers that helped us improving the paper.

\section{REFERENCES}

Anbari, F. T. 2003. Earned Value Project Management Method and Extensions. Project Management Journal 34(4): 12-23, DOI 10.1109/EMR.2004.25113.

Antvik, L. C. S. 1998. Earned Value Management: A 200 Year Perspective. Long Beach (CA): 29th Annual Project Management Institute Seminars and Symposium.

Aram, J. D., and K. Walochik. 1997. Improvisation and the Spanish Manager-Cultural Values and Management Style in Spain. Int. Studies of Mgt. \& Org. 26(4): 73-89, www.jstor.org/stable/40397356.

Bower, D. C. 2007. New Directions in Project Performance and Progress Evaluation. Melbourne (Australia): Unpublished PhD Thesis, RMIT University. 
Brandon, D. M. 1998. Implementing Earned Value Easily and Effectively. Project Management Journal 29(2): 11-18.

Brown, A., and J. Adams. 2000. Measuring the Effect of Project Management on Construction Outputs: A New Approach. International Journal of Project Management 18(5): 327-335, DOI: 10.1016/S0263-7863(99)00026-5.

Bryde, D. J. 2003. Modelling Project Management Performance. International Journal of Quality \& Reliability Management 20(2): 229-254, DOI: 10.1108/02656710310456635.

Chen, H. L., Chen, W. T., and Lin, Y. L. 2016. Earned Value Project Management: Improving the Predictive Power of Planned Value. International Journal of Project Management. 34(1): 22-29.

Cioffi, D. F. 2004. Work and Resource Breakdown Structures for Formalized Bottom-Up Estimating. Cost Engineering 46(2): 31-37.

Crawford, J. K. 2002. Project Management Maturity Model: Providing a Proven Path to Project Management Excellence. New York: Marcel Dekker.

Creswell, J. W. 1994. Research Design: Qualitative and Quantitative Approaches. Thousand Oaks (CA): Sage.

de la Cruz, M. P., A. del Caño, and E. de la Cruz. 2006. Downside Risks in Construction Projects Developed by the Civil Service: The Case of Spain. Journal of Construction Engineering and Management 132(8): 844-852, DOI: 10.1061/(ASCE)07339364(2006)132:8(844).

de Vaus, D. A. 1996. Surveys in Social Research (4 ${ }^{\text {th }}$ Ed.). London: UCL Press.

Din, S., Z. Abd-Hamid, and D.J. Bryde. 2011. ISO 9000 Certification and Construction Project Performance: The Malaysian Experience. International Journal of Project Management 29(8): 1044-1056, DOI: 10.1016/j.ijproman.2010.11.001. 
Dinsmore, P. C. 1998. How Grown-Up is your Organization? PM Network 12(6): 24-26.

Eldin, N.N. 1989. Measurement of Work Progress: Quantitative Technique. Journal of Construction Engineering and Management 115(3): 462-474, DOI: 10.1061/(ASCE)0733-9364(1989)115:3(462).

Fellows, R., and A. Liu. 1997. Research Methods for Construction. Oxford: Blackwell. Fitzmaurice, G., N. Laird, and J. Waire. 2004. Applied Longitudinal Analysis. Hoboken (NJ): Wiley.

Fleming, Q.W., and J.M. Koppelman. 2005. Earned Value Project Management ( ${ }^{\text {rd }}$ Ed.). Newton Square (PA): Project Management Institute.

Gidado, K.I. 1996. Project Complexity: The Focal Point of Construction Production Planning. Construction Management and Economics 14(3): 213-25, DOI: 10.1080/014461996373476.

Grant, K.P., and J.S. Pennypacker. 2006. Project Management Maturity: An Assessment of Project Management Capabilities Among and Between Selected Industries. IEE Transactions on Engineering Management 53(1): 59-68, DOI: 10.1109/TEM.2005.861802.

Hastak, M., D.W. Halpin, and J. Vanegas. 1996. COMPASS-New Paradigm for Project Cost Control Strategy and Planning. Journal of Construction Engineering and Management 122(3): 254-264, DOI: 10.1061/(ASCE)0733-9364(1996)122:3(254).

Hendrickson, C. T., and T. Au. 1989. Project Management for Construction: Fundamental Concepts for Owners, Engineers, Architects, and Builders. Englewood Cliffs (NJ): Prentice Hall.

Holt, G.D., and Goulding, J.S. 2014. Conceptualisation Of Ambiguous-Mixed-Methods Within Building And Construction Research. Journal of Engineering, Design and Technology 12 (2):244-262, DOI:10.1108/JEDT-02-2013-0020. 
Howard, A. G. 2012. Missing Data in Non-Parametric Tests of Correlated Data.

Unpublished PhD Dissertation. Chapel Hill (NC): University of North Carolina.

Ibbs, C.W., and Y.H. Kwak. 2000. Assessing Project Management Maturity. Project Management. Journal 31(1): 32-43.

Ibbs, C.W., D.B. Ashley, J.M. Neil., and F.W. Feiler. 1987. An Implementation Strategy for Improving Project Control Systems. In: C.W. Ibbs, and D.B. Ashley (Eds.) Project Controls: Needs and Solutions. ASCE Proc. Speciality Conf.: 101-112.

Jugdev, K., and J. Thomas. 2002. Project Management Maturity Model: The Silver Bullet of Competitive Advantage? Project. Management. Journal 33(4): 4-14.

Kerzner, H. 2005. Using the Project Management Maturity Model ( $2^{\text {nd }}$ Ed.). Hoboken (NJ): Wiley.

Kim, E. H., Wells Jr. W. G. and Duffey, M. R. 2003. A model for Effective Implementation of Earned Value Management Methodology. International Journal of Project Management 21(5): 375-382. doi:10.1016/S0263-7863(02)00049-2.

Kim, S. B. 2014. Impacts of Knowledge Management on the Organizationlal Success. KSCE Journal of Civil Engineering 18(6): 1609-1617, DOI: 10.1007/s12205-014-0243-6.

Kim, T., Kim, Y. and Cho, H. 2016. Customer Earned Value: Performance Indicator From Flow and Value Generation View. Journal of Management in Engineering 32(1): 04015017, DOI: 10.1061/(ASCE)ME.1943-5479.0000377.

Koskela, L., and G. Howell. 2002. The Underlying Theory of Project Management is Obsolote. Proceedings of the PMI Research Conference 2002: 293-302.

Laufer, A. and R.L. Tucker. 1987. Is Construction Project Planning Really Doing its Job? A Critical Examination of Focus, Role and Process. Construction Management and Economics 5(3): 243-266, DOI: 10.1080/01446198700000023. 
Liberatore M.J., B. Pollack-Johnson, and C.A. Smith. 2001. Project Management in Construction: Software Use and Research Directions. Journal of Construction Engineering and Management 127: 101-107, DOI: 10.1061/(ASCE)07339364(2001)127:2(101).

Marshall, R.A., Ruiz, P. and Bredillet, C. N. 2008. Earned Value Management Insight Using Inferential Statistics. International Journal of Managing Project in Business (2): 288294, DOI 10.1108/17538370810866386.

Marzouk, M., and M. Hisham. 2014. Implementing Earned Value Management using Bridge Information Modeling. KSCE Journal of Civil Engineering 18(5): 1302-1313, DOI: 10.1007/s12205-014-0455-9.

Miles, M.B., Huberman, A.M. an Saldaña, J. 2013. Qualitative Data Analysis: A Methods Sourcebook ( $3^{\text {rd }}$ ed.). Thousand Oaks, CA: Sage.

Mir, F.A., and A.H. Pinnington. 2014. Exploring the Value of Project Management: Linking Project Management Performance and Project Success. International Journal of Project Management 32(2): 202-217, DOI: 10.1016/j.ijproman.2013.05.012.

NAO. 2005. Driving the Successful Delivery of Major Defence Projects: Effective Project Control is a Key Factor in Successful Projects, National Audit Office. London: The Stationery Office.

Navon, R., and I. Haskaya. 2006. Is Detailed Progress Monitoring Possible without Designated Manual Data Collection? Construction Management and Economics 24(12): 1225-1229, DOI: 10.1080/01446190600999097.

Nima, M.A., M.R. Abdul-Kadir, and M.S. Jaafar. 2001. Evaluation of the Role of The Contractor's Personnel in Enhancing the Project Constructability. Structural Survey 19(4): 193-200, DOI:10.1108/EUM0000000005840. 
Onwuegbuzie, A.J., and K.M.T. Collins. 2007. A Typology of Mixed Methods Sampling Designs in Social Science Research. The Qualitative Report 12(2): 281-316.

Onwuegbuzie, A.J., and N.L. Leech. 2005. Taking the “Q” Out of Research: Teaching Research Methodology Courses without the Divide between Quantitative and Qualitative Paradigms. Quality \& Quantity: International Journal of Methodology 39: 267-296, DOI:10.1007/s11135-004-1670-0.

Oviedo-Haito, R.J., J. Jiménez, F.F. Cardoso, and E. Pellicer. 2014. Survival Factors for Subcontractors in Economic Downturns. Journal of Construction Engineering and Management 140(3): 04013056, DOI:10.1061/(ASCE)CO.1943-7862.0000811.

Pellicer, E., Sanz, M.A., Esmaeili, B., Molenaar, K.R. 2016 Exploration of Team Integration In Spanish Multi-Family Residential Building Construction”. Journal of Management in Engineering 32(5): 05016012, DOI: 10.1061/(ASCE)ME.1943-5479.0000438.

Pellicer, E., and R. Victory. 2006. Implementation of Project Management Principles in Spanish Residential Developments. International Journal of Strategic Property Management 10: 233-248, DOI: 10.1080/1648715X.2006.9637555.

Picornell, M., Pellicer, E., Torres-Machi, C., and Sutrisna, M. 2016. Implementation of Earned Value Management in Unit-Price Payment Contracts. Journal of Management in Engineering, in press, DOI: 10.1061/(ASCE)ME.1943-5479.0000500

PMI. 2013. A Guide to the Project Management Body of Knowledge - PMBOK Guide, $\left(5^{\text {th }}\right.$ Ed.). Newton Square (PA): Project Management Institute.

Potts, K. 2008. Construction Cost Management: Learning from Case Studies. Oxon: Taylor \& Francis.

Rad, P.F. 1999. Advocating a Deliverable-Oriented Work Breakdown Structure. Cost Engineering 41(12): 35-39. 
Rasdorf, W.J., and O.Y. Abudayyeh. 1991. Cost- and Schedule-Control Integration: Issues and Needs. Journal of Construction Engineering and Management 117(3): 486-502, DOI: 10.1061/(ASCE)0733-9364(1991)117:3(486).

Robson, C. 2011. Real World Research - A Resource for Social Scientists and PractitionerResearchers ( ${ }^{\text {rd }}$ Ed.). Oxford: Blackwell.

SEOPAN. 2016. Informe Económico2015. Madrid: ANCOP (in Spanish).

Sertyesilisik, B. 2016. A Preliminary Study on the Regenerative Constructino Project Management Concept for Enhancing Sustainability Performance of the Construction Industry. International Journal of Construction Management, in press.

Suk, S.J., S. Chi, S.P. Mulva, C.H. Caldas, and S.H. An. 2016. Quantifying Combination Effects of Project Management Practices on Cost Performance. KSCE Journal of Civil Engineering in print, DOI 10.1007/s12205-016-0499-0.

Sutrisna, M. 2009. Research Methodology in Doctoral Research: Understanding the meaning of Conducting Qualitative Research. Working Paper, ARCOM Doctoral Workshop, Liverpool, 12 May 2009. Association of Researchers in Construction Management (ARCOM), UK.

Sutrisna, M., E. Pellicer, M. Picornell, and C. Torres-Machi. 2013. Analysing the Potential Application of the Earned Value Management (EVM) in the Spanish Construction Industry: An Initial Review of the Dataset. In: Vimonsatit, V., A. Singh, and S. Yazdani (Eds.). Proceedings of the 1st Australasia and South East Asia Conference in Structural Engineering and Construction (ASEA-SEC-1): 1003-1008.

Sutrisna, M., E. Pellicer, C. Torres-Machí, and M. Picornell. 2012. Enabling Implementation of Earned Value Management in the Spanish Construction Industry. In: Kashiwagi, D., and K. Sullivan (Eds.). Proceedings of RICS COBRA 2012 Conference: 15711578. 
Thamhain, H. J. 1998. Integrating Project Management Tools with the Project Team. Long Beach (CA): 29th Annual Project Management Institute Seminars and Symposium.

Thomas, J., and M. Mullaly. 2008. Researching the Value of Project Management. Newton Square (PA): Project Management Institute.

Vanhoucke, M. 2012. Project Management with Dynamic Scheduling: Baseline Scheduling, Risk Analysis and Project Control. Heidelberg: Springer.

Winch, G. H. 2002. Managing Construction Projects. London: Blackwell.

Yazici, H. J. 2009. The Role of Project Management Maturity and Organizational Culture in Perceived Performance. Project Management Journal 40(3): 14-33, DOI: 10.1002/pmj.20121.

Yin, R. K. 2013. Case Study Research: Design and Methods, (5 ${ }^{\text {th }}$ Ed.). Thousand Oaks (CA): Sage.

Yu, A.G, P.D. Flett, and J.A. Bowers. 2005. Developing a Value-Centred Proposal for Assessing Project Success. International Journal of Project Management 23: 428436, DOI: 10.1016/j.ijproman.2005.01.008. 
Table 1. Characteristics of the respondents.

\begin{tabular}{llr}
\hline Number of responses analysed & & 56 \\
\hline Respondents' work level & Strategic Management & $5.35 \%$ \\
& Middle Management & $39.28 \%$ \\
& Site Management & $57.14 \%$ \\
& N/A & $7.14 \%$ \\
\hline Respondents' experience in & Min & 5 \\
construction & Max & 31 \\
(in years) & Median & 14 \\
& Mean & 13 \\
\hline
\end{tabular}


Table 2. The state-of-art project management in Spanish construction industry.

\begin{tabular}{|c|c|c|c|}
\hline The state-of-art project management & $\sum w$ & $\bar{x}$ & Md \\
\hline $\begin{array}{l}\text { The need for further use and application of the project } \\
\text { management tools/techniques in construction in Spain }\end{array}$ & 34 & 0.62 & 1 \\
\hline $\begin{array}{l}\text { Familiarity and acceptance of project management concepts } \\
\text { the construction industry in Spain }\end{array}$ & 28 & 0.51 & 1 \\
\hline Recognition of project management tools/techniques in Spain & -4 & -0.07 & 0 \\
\hline Acceptance of project management tools/techniques in Spain & -9 & -0.16 & 0 \\
\hline $\begin{array}{l}\text { Implementation/use of project management tools/techniques in } \\
\text { construction sectors in Spain }\end{array}$ & 9 & 0.16 & 0 \\
\hline
\end{tabular}


Table 3. Project management focus in Spanish construction industry.

\begin{tabular}{lc}
\hline Construction project management focus & Average rank \\
\hline Cost & 1.53 \\
\hline Time & 2.70 \\
\hline Quality & 2.90 \\
\hline Health \& Safety & 3.19 \\
\hline Sustainability & 4.69 \\
\hline Others: & N/A \\
\hline Customer's satisfaction & \\
Personal relations & \\
Public relations & \\
\hline $\mathrm{n}=56$ & \\
$\lambda^{2}=120.082$ & \\
$\mathrm{df}=4$ & \\
$\boldsymbol{\rho}<0.000$ & \\
\hline
\end{tabular}


Table 4. Construction project planning in Spanish construction industry.

\begin{tabular}{|c|c|c|c|}
\hline Construction project planning & $\sum w$ & $\bar{x}$ & Md \\
\hline $\begin{array}{l}\text { Prior to project tender in Spain, an estimation of the cost for } \\
\text { each activity in the WBS of the programme is prepared }\end{array}$ & 44 & 0.80 & 1 \\
\hline $\begin{array}{l}\text { The estimation of the project cost is mainly based on the } \\
\text { quantity }\end{array}$ & 32 & 0.58 & 1 \\
\hline $\begin{array}{l}\text { Upon a sucessfull tender, a new/different project budget and } \\
\text { programme is normally prepared for construction phase }\end{array}$ & 63 & 1.15 & 1 \\
\hline $\begin{array}{l}\text { The (new) programme prepared will determine the project } \\
\text { execution to the level of activities in WBS }\end{array}$ & 40 & 0.73 & 1 \\
\hline
\end{tabular}


Table 5. Factors considered in preparing project budget and programme in Spanish construction.

\begin{tabular}{lc}
\hline Factors considered & Average rank \\
\hline Quantity of work & 1.72 \\
\hline Expected rate of productivity (resources) & 2.75 \\
\hline The duration of the activities & 2.89 \\
\hline Type of activities & 3.21 \\
\hline Health \& safety and sustainability & 4.43 \\
\hline Others: & N/A \\
\hline $\begin{array}{l}\text { Direct/indirect cost } \\
\text { Weather condition }\end{array}$ \\
Project (geographical) location \\
\hline $\mathrm{n}=55$ \\
$\lambda^{2}=86.096$ \\
$\mathrm{df}=4$ \\
$\boldsymbol{\rho}<0.000$
\end{tabular}


Table 6. Construction progress and actual cost monitoring in Spanish construction industry.

\begin{tabular}{|c|c|c|c|}
\hline Construction progress and actual cost monitoring & $\sum w$ & $\bar{x}$ & Md \\
\hline $\begin{array}{l}\text { The tracking of construction progress are done only to comply } \\
\text { with the contractual requirements and for progress payment }\end{array}$ & -59 & -1.09 & -1 \\
\hline $\begin{array}{l}\text { The tracking of the project progress are done using the record } \\
\text { of project expenditure so far }\end{array}$ & 27 & 0.49 & 1 \\
\hline $\begin{array}{l}\text { The actual costs or project expenditure are recorded based on } \\
\text { cost centres mapped to WBS }\end{array}$ & 40 & 0.73 & 1 \\
\hline $\begin{array}{l}\text { The actual costs or project expenditure of a construction } \\
\text { project are recorded on a daily basis }\end{array}$ & -35 & -0.64 & -1 \\
\hline $\begin{array}{l}\text { The actual project expenditure are evaluated against the } \\
\text { original budget at the end of a specific period }\end{array}$ & 3 & 0.05 & 0 \\
\hline $\begin{array}{l}\text { The tracking of the progress are on the \% completion of } \\
\text { activities in the WBS }\end{array}$ & 5 & 0.09 & 0.5 \\
\hline $\begin{array}{l}\text { The tracking of the progress are done by actually measuring } \\
\text { the physical progress for progress payment purpose }\end{array}$ & 5 & 0.09 & 0.5 \\
\hline
\end{tabular}


FIGURE CAPTION LIST

Figure 1: Transition from existing practice to implementing EVM in Spain. 


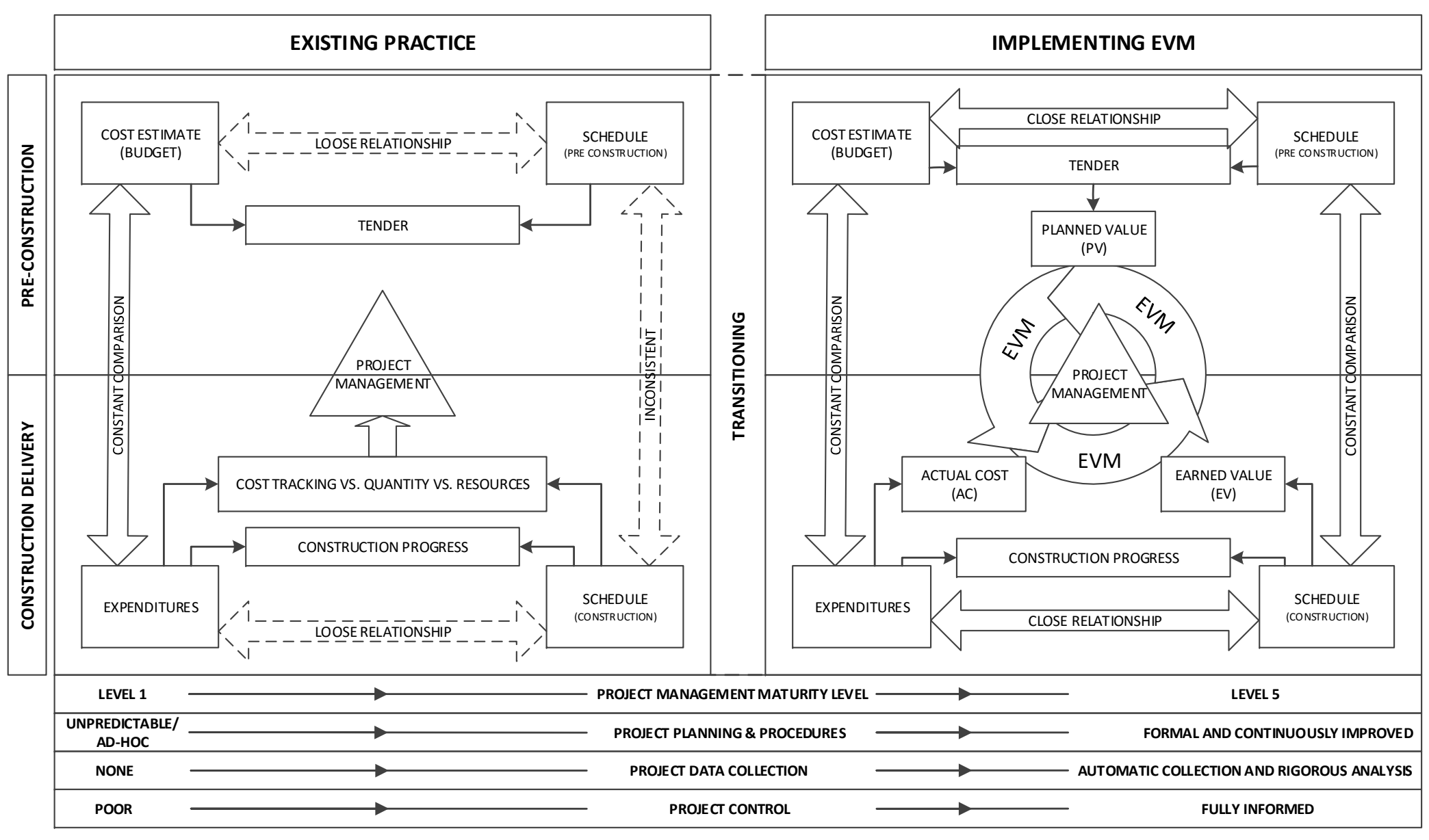

